\title{
Interleukin 2 production in a family with systemic lupus erythematosus and a $\mathrm{C} 4 \mathrm{Q} 0$ heterozygous inheritance
}

Carmen Gutierrez, Esther Cabrero, José L Vicario, Manuel Martín Villa, Miguel A Rengel, Francisco J Gomez Campdera, Miguel Yebra, Eduardo Fernández-Cruz, Antonio Arnaiz Villena

\begin{abstract}
Interleukin 2 production was studied in a family with systemic lupus erythematosus (SLE) and a C4Q0 heterozygous inheritance. Autoimmune manifestations seemed to be associated with the HLA haplotype containing the CAQO allele, which was shared by all four ill family members. Concentrations of interleukin 2, however, did not associate either with the haplotype or with the clinical or serological manifestations, as diminished concentrations of interleukin 2 were found in only two subjects with SLE. Thus the defect in this family seemed to be acquired rather than genetically conditioned.
\end{abstract}

Since the pioneering descriptions of a deficient production of interleukin 2 in autoimmune animal models ${ }^{12}$ a series of reports have described defects in the production of interleukin 2 in response to allogeneic signals and mitogens by lymphocytes from patients with systemic lupus erythematosus (SLE). ${ }^{3-6}$ This defect could not be corrected by addition of exogenous interleukin $1^{45}$ and apparently did not correlate with disease activity as decreased concentrations of interleukin 2 have been found in patients with active and inactive disease. ${ }^{7}$ Other investigators have suggested that the defect may be an in vitro effect due to exhaustion of lymphocytes by excessive function in vivo. ${ }^{8}$ Furthermore, it has been suggested that low concentrations of interleukin 2 are the consequence of a compensatory mechanism to control an exaggerated $T$ cell activation, and therefore beneficial for the patients. ${ }^{9}$ These two last hypotheses are difficult to reconcile with an increased production of $\mathbf{B}$ cell differentiation factor by lupus lymphocytes. ${ }^{7} 1011$ Suppressor factors secreted by CD8 cells from lupus patients have also been reported in association with defective production of interleukin $2 .^{12}$

The abnormal production of interleukin 2 in SLE may be (a) a genetically determined primary defect, (b) a collateral phenomenon associated with a generalised immunodysregulation of unknown origin; (c) secondary to clinical or serological autoimmune manifestations, or both. It has been suggested that the interleukin 2 deficiency in SLE is not a genetic trait because it may be corrected by superinduction with phorbol myristic acetate. ${ }^{13}$ Genetically determined immunoregulatory aberrations, however, may underlie the need for phorbol myristic acetate to secrete normal amounts of interleukin 2 in response to mitogens.

The origin of lymphokine mediated immune dysfunction in SLE may be elucidated by a study of families with more than one member with the disease. In this report the production of interleukin 2 in several members of a family with SLE and a C4Q0 heterozygous inheritance is described.

\section{Patients and methods}

\section{PROBAND AND FAMILY MEMBERS}

The proband, a 15 year old boy who had been diagnosed with idiopathic thrombocytopenic purpura three years previously, was admitted to the Hospital Gregorio Marañón in May 1986. He had anorexia, asthenia, fever, haematuria, and severe proteinuria. The serological tests on admission yielded antinuclear antibodies at a titre of $>1 / 640$, anti-dsDNA antibodies $>100$ $\mathrm{U} / \mathrm{ml}$, anti-Ro antibodies $1 / 128$, and hypocomplementaemia. A percutaneous renal biopsy showed mesangial proliferative glomerulonephritis, and a diagnosis of SLE was established. Treatment was started with oral prednisone $1 \mathrm{mg} / \mathrm{kg}$ daily. Owing to a poor clinical response, treatment was changed to intravenous pulse methylprednisolone $15 \mathrm{mg} / \mathrm{kg}$ daily and cyclophosphamide $2 \mathrm{mg} / \mathrm{kg}$ daily. Two months later the renal function had returned to normal and treatment was continued with low doses of prednisone $(20 \mathrm{mg} / \mathrm{day})$. At the time of the study the patient was asymptomatic and was receiving $10 \mathrm{mg}$ of prednisone every other day.

The proband's mother was diagnosed as having autoimmune thrombocytopenia. She was asymptomatic at the time of the study, but laboratory tests showed thrombocytopenia and antinuclear antibodies at a titre of $1 / 160$ with a nucleolar pattern. Tests for other autoantibodies were negative. The proband's father and 12 year old sister were normal. Two maternal aunts (II.1 and II.2) were studied at the Clínica Puerta de Hierro. Aunt II.1, aged 54, had probable SLE manifested by asthenia, headache, polyarthritis, muscular pain, oral ulcers, and a positive Schirmer's test. Laboratory analysis showed antinuclear antibodies $>1 / 640$; tests for the other autoantibodies were negative. Complement concentrations were normal. At the time of the study she was not receiving treatment, but a few months later she showed clinical deterioration and steroid treatment (10 $\mathrm{mg} /$ day) was started. The other maternal aunt (II.2), aged 41, presented with malar rash, photosensitivity, polyarthralgias, headache, salivary gland swelling, xerostomia, a positive Schirmer's test, and a salivary biopsy specimen compatible with Sjögren's syndrome. A diagnosis of SLE and Sjögren's syndrome was 
made. The immunological tests were positive for antinuclear antibodies at a titre of $1 / 160$ and anti-Ro antibodies at $1 / 128$. The maternal uncle was asymptomatic and refused immunological studies. The proband's three cousins (III.1III.3) were normal. Five healthy subjects (four female, one male, aged 20 to 42 ) served as controls.

\section{SEROLOGICAL TESTS}

Antinuclear antibodies were determined by standard immunofluorescence techniques using rat tissue prepared in the laboratory and commercial tumorous HEp-2 cells (Kallestad, Austin, Texas). Anti-dsDNA antibodies were detected by radioimmunoassay (Amersham International, UK), and precipitated antibodies against antigens UIRNP, Sm, Ro(SS-A), and $\mathrm{La}(\mathrm{SS}-\mathrm{B})$ by counterimmunoelectrophoresis using a saline extract of rabbit thymus powder (Pel Freez, Rogers, Arkansas) and an extract of human spleen prepared as previously described. ${ }^{14}$ Antibody specificity was defined using prototype serum samples donated by the Center for Disease Control, Atlanta, GA. C3 concentrations were determined by nephelometric analysis.

INDUCTION OF AND FUNCTIONAL ASSAY FOR INTERLEUKIN 2

Conditioned supernatants were obtained by culturing $5 \times 10^{6}$ peripheral blood lymphocytes in culture medium with $1 \%$ fetal calf serum and $10 \mu \mathrm{g} / \mathrm{ml}$ phytohaemagglutinin for 24 hours. ${ }^{7}$ Interleukin 2 activity in the supernatant was determined by using L2 murine cytotoxic T lymphocytes. ${ }^{15}$ Briefly, test supernatant or interleukin 2 standard supernatant was doubly diluted in a flat bottomed 96 well microtitre plate and $5 \times 10^{3} \mathrm{~L} 2$ cytotoxic T lymphocytes were added to each well. Proliferation was assayed by $\left[{ }^{3} \mathrm{H}\right]$ thymidine incorporation 24 hours later. The supernatant concentration which caused half maximal $\left[{ }^{3} \mathrm{H}\right]$ thymidine incorporation was defined as $1 \mathrm{U} / \mathrm{ml}$. Values from each patient's supernatant were classified in relation to the frequency distribution of the controls. Statistical significance was determined with Student's $t$ test.

\section{HLA TYPING}

Class I and II antigens were detected by standard microlymphocytotoxicity techniques. ${ }^{16}$ C4 typing was carried out by electrophoresis of serum samples followed by immunofixation ${ }^{17}$; $\mathrm{Bf}$ allele detection ${ }^{18}$ and $\mathrm{C} 2$ typing by isoelectrofocusing and immunofixation were carried out as previously described. ${ }^{19}$

\section{Results and discussion}

This work was carried out in an attempt to explain the origin of the deficient production of
Pedigree and HLA haplotypes of kindred members.

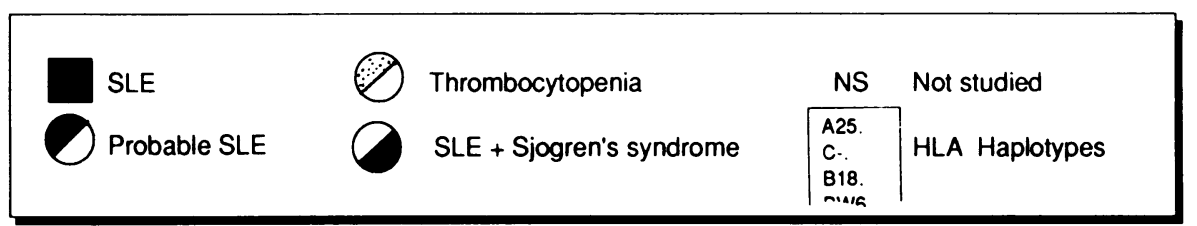

I

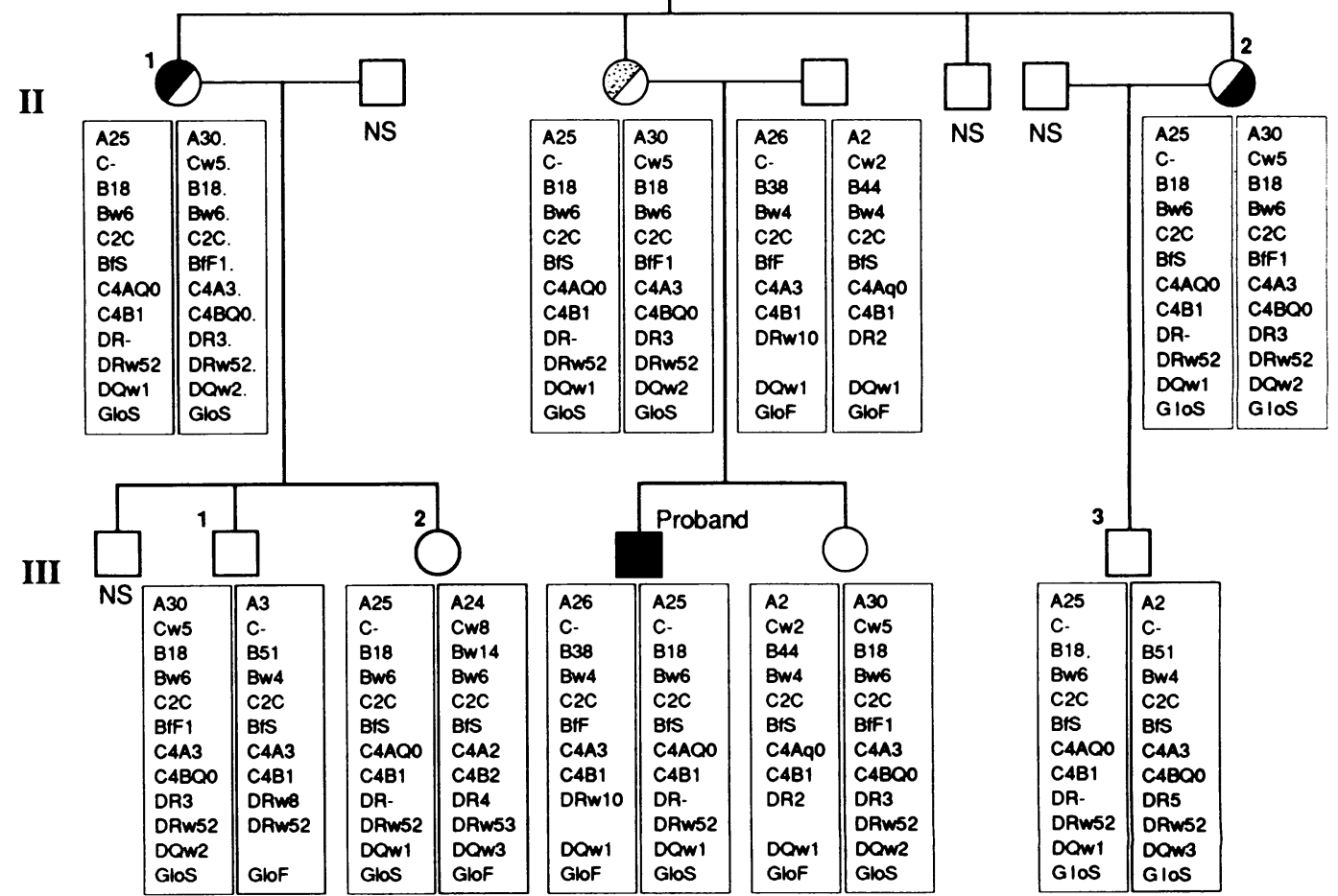


Interleukin 2 (IL2) production in proband and family members in relation to immunological and clinical features

\begin{tabular}{|c|c|c|c|c|c|c|}
\hline \multirow{2}{*}{$\begin{array}{l}\text { Family } \\
\text { members }\end{array}$} & \multicolumn{2}{|l|}{ Clinical data } & \multicolumn{3}{|c|}{ Serological findings } & \multirow{2}{*}{$\begin{array}{l}\text { IL2 production } \\
(\text { U/ml })\end{array}$} \\
\hline & Diagnosis & Treatment & ANAT‡ & $D N A(U / m l)$ & $\begin{array}{l}\text { Precipitating } \\
\text { autoantibodies }\end{array}$ & \\
\hline $\begin{array}{l}\text { Proband } \\
\text { Oct 1986* } \\
\text { Apr } 1987 \\
\text { Nov 1987 } \\
\text { Father } \\
\text { Mother } \\
\text { Sister }\end{array}$ & $\begin{array}{l}\text { SLE† } \\
\text { Healthy } \\
\text { Autoimmune thrombocytopenia } \\
\text { Healthy }\end{array}$ & $\begin{array}{l}\text { Prednisone }(20 \mathrm{mg} / \mathrm{d}) \\
\text { Prednisone }(10 \mathrm{mg} \text { alt. days) } \\
\text { Prednisone }(10 \mathrm{mg} \text { alt. days) } \\
\text { None } \\
\text { None } \\
\text { None }\end{array}$ & $\begin{array}{l}80, \mathrm{H}, \mathrm{S} \\
160, \mathrm{H}, \mathrm{S} \\
\text { Not studied } \\
\overline{80}, \text { No } \\
-\end{array}$ & $\begin{array}{r}78 \\
6 \\
8 \\
-4 \\
-\end{array}$ & $\begin{array}{l}\text { Ro }(8) \Omega \\
\text { Not studied } \\
\text { Not studied } \\
= \\
=\end{array}$ & $\begin{array}{l}<0.07 \| \\
<0.07^{\| \prime} \\
<0.07^{\| \prime} \\
0.52 \\
1.53 \\
0.62\end{array}$ \\
\hline $\begin{array}{l}\text { Aunt II.I } \\
\text { Jan } 1987 \\
\text { Nov 1987 } \\
\text { Aunt II. } \\
\text { Cousin III.1 } \\
\text { Cousin III.2 } \\
\text { Cousin III.3 } \\
\text { Controls }(n=5)\end{array}$ & $\begin{array}{l}\text { Probable SLE } \\
\text { SLE+ SST } \\
\text { Healthy } \\
\text { Healthy } \\
\text { Healthy }\end{array}$ & $\begin{array}{l}\text { None } \\
\text { Prednisone }(10 \mathrm{mg} / \mathrm{d}) \\
\text { None } \\
\text { None } \\
\text { None } \\
\text { None }\end{array}$ & $\begin{array}{l}\text { 640, H } \\
640, \mathrm{H} \\
.160, \mathrm{H}, \mathrm{s} \\
= \\
=\end{array}$ & $\begin{array}{r}7 \\
9 \\
14 \\
= \\
-\end{array}$ & $\begin{array}{l}\overline{\overline{R o}} \\
\overline{-} \\
=\end{array}$ & $\begin{array}{l}<0.077^{\prime \prime} \\
.0 .07^{\prime \prime} \\
0.21 \\
\text { Not done } \\
0.84 \\
0.94 \\
0.46(0.13)\end{array}$ \\
\hline
\end{tabular}

* Date of follow up visits.

†ANA=antinuclear antibodies; SLE=systemic lupus erythematosus; SS=Sjögren's syndrome.

\#eciprocal of the titre and fluorescence pattern: $\mathrm{H}=$ homogeneous; $\mathrm{S}=$ speckled; No=nucleolar

SSpecificity of antibodies to extractable nuclear antigens. In parentheses the reciprocal of the titre. Significant by Student's $t$ test; $p<0.05$.

interleukin 2 in subjects with SLE. With this aim major histocompatibility complex antigens and mitogen induced secretion of interleukin 2 were determined in several members of a family with SLE. The figure shows the pedigree and HLA haplotypes of this family. The table shows the concentrations of interleukin 2 induced by phytohaemagglutinin and the serological and clinical features of each family member. Undefined genetic factors, probably linked to the genome of the proband's mother, seemed to account for the disease process, as only the proband's mother and her first degree relatives had autoimmune manifestations. The genetic causative agent could be associated with the HLA haplotype-A25, B18, Bw6, DRX, DQwl, DRw52, C4AQ0, C4B1, C2C, BfS, GloSshared by all affected members and carrying the $\mathrm{C4Q0}$ allele, which has been described as more prevalent among those with SLE, ${ }^{20}{ }^{21}$ even if present in heterozygosity. However, two healthy members (cousins III.2 and III.3) also carried this haplotype, suggesting either that the genetic autoimmune inducing factors in this family were not linked to this haplotype, or, alternatively, that uncontrolled environmental factors contributed to the full expression of the disease. Genetic and environmental factors are probably both required for the manifestation of the illness. On the other hand, cousins III. 2 and III. 3 may develop autoimmune phenomena in the future as at the time of the study they were quite young - 20 and 6 years of age respectively.

The table shows that three blood samples from the proband and two from aunt (II.1), both severely affected, had undetectable concentrations of interleukin 2 in a phytohaemagglutinin induced supernatant. In another affected member (aunt II.2), however, who had severe symptoms and serological alterations, including anti-Ro antibodies, the decrease in concentration of interleukin 2 was not statistically significant. In addition, the proband's mother, who had autoimmune thrombocytopenia and who also had antinuclear antibodies, produced normal amounts of interleukin 2. All other family members behaved normally in lymphokine analysis. Attention is drawn to the fact that although the first conditioned supernatant from the proband was obtained while the patient was receiving $20 \mathrm{mg} /$ day prednisone (October 1986), this was not considered to have been the cause of the reduced interleukin 2 production as two subsequent samples, drawn while the patient was receiving maintenance dose of steroids (10 mg on alternate days), yielded similar results. In addition, an abnormal $\mathrm{T}$ cell distribution did not seem to influence the results as flow cytometric analysis showed normal relative numbers of $\mathrm{CD} 4+$ cells in peripheral lymphocytes of the proband and aunt II.1 (data not shown).

The above results indicate that interleukin 2 deficiency in SLE is not a genetically conditioned primary defect. If the defect were genetically determined and linked to an autoimmune trait, all affected members would be expected to synthesise low concentrations of interleukin 2 . Two subjects with autoimmune disease secreted normal amounts of interleukin 2, however. Furthermore, the defect did not seem to be a consequence of autoantibody-cell antigen interactions or receptor occupancy by immune complexes as some patients secreted autoantibodies while producing interleukin 2 in normal concentrations.

Although more families should be studied before reaching a definite conclusion, our data indicate that interleukin 2 deficiency in SLE is an acquired rather than a genetic defect. Similar conclusions were obtained in a recent study of interleukin 2 production in monozygotic twins with SLE. ${ }^{22}$ This work was supported by grants from the Fondo de
Investigaciones Sanitarias de la Seguridad Social FISss $85 / 1009$ and $86 / 776$.

1 Dauphinee M J, Kippe S B, Wofsy D, Talal N. Interleukin 2 deficiency is a common feature of autoimmune mice. deficiency is a common feat

F Immunol 1981; 127: 2483-7. $F$ J. Analysis of the $T$ cell function in autoimmune murine $F$ J. Analysis of the $T$ cell function in autoimmune murine strains. Defects in production of and responsi
interleukin 2. ₹ Exp Med 1981; 154: 791-808.

3 Alcocer-Varela J, Alarcón-Segovia D. Decreased production of and response to interleukin 2 by cultures of lymphocytes from patients with lupus erythematosus. $\mathcal{F}$ Clin Invest 1982 69: 1388-92.

4 Linker-Israeli M, Bakke A C, Kitridou R C, Gendler S, Gillis $S$, Horwitz D. Defective production of interleukin 1 and interleukin 2 in patients with systemic lupus erythematosus. f Immunol 1983; 130: 2651-5. 
5 Murakawa Y, Takada S, Ueda Y, Suzuki N, Hoshino T, Sakane T. Characterization of $T$ lymphocyte subpopulation responsible for deficient interleukin 2 activity in patients with systemic lupus erythematosus. F Immunol 1985; 134 187-95.

6 Gaspar M L, Alvarez de Mon M, Gutierrez C. Controversia role of interleukin 2 in inducing normalization of natura killer activity in systemic lupus erythematosus. Clin Immunol Immunopathol 1988; 49: 204-14.

7 Gaspar M L, Alvarez de Mon M, Gutierrez C. B cell activation pathway in human systemic lupus erythematosus (SLE) "in vitro" lymphokine imbalance and association with analytical findings. $f$ Clin Immunol 1988; 8: 266-74.

8 Huang Y P, Miescher P A, Zubler R H. The interleukin 2 secretion defect "in vitro" in systemic lupus erythematosus is reversible in rested cultured T cells. F Immunol 1986; 137: $3515-20$

9 Kroemer G, Wick G. The role of interleukin 2 in auto immunity. Immunol Today 1989; 10: 246-51.

10 Hirose T, Hara M, Kitani A, et al. Abnormal production of and response to $B$ cell growth factor and $B$ cell differentiation factor in patients with systemic lupus erythematosus. Scand 7 Immunol 1985; 21: 141-50.

11 Martinez-Cordero E, Alcocer-Varela J, Alarcón-Segovia D. Stimulating and differentiation factors for human $B$ lymphocytes in systemic lupus erythematosus. Clin Exp Immunol 1986; 65: 598-604.

12 Linker-Israeli M, Bakke A C, Quismorio F P, Horwitz D. Correction of interleukin 2 production in patients with systemic lupus erythematosus by removal of spontaneously activated suppressor cells. $\mathcal{f}$ Clin Invest 1985; 75: 762-8.

13 Santoro T J, Luger T A, Raveche E S, Smolen J S, Oppenheim J J, Steinberg A D. In vitro correction of the interleukin 2 defect of autoimmune mice. Eur $\mathcal{Y}$ Immunol 1983; 13: $601-4$.

14 Slopelitis E, Biundo Jr J J, Alspaugh M A. Anti-SS-A antibody and other antinuclear antibodies in systemic lupus erythematosus. Arthritis Rhewam 1980; 23: 287-93.

15 Gillis S, Ferm $M$, Ou W, Smith $K$. T cell growth factor parameters of production and a quantitative microassay for activity. F Immunol 1978; 120: 2027-32.

16 Mittal K K, Mickey M R, Singal D P, Terasaki P I Serotyping for hemotransplantation: XVIII. Refinement of micro-droplet lymphocyte cytotoxicity test. Transplantation 1968; 6: 913.

17 Regueiro J R. Arnaiz Villena A. Human MHC class III (Bf C2, C4) genes and GLO: their association with other HLA antigens and extended haplotypes in the Spanish popuantigens and extended haplotypes in the
lation. Tissue Antigens 1988; 31: 14-25.

18 Rodriguez-Córdoba S, Bootello A, Arnaiz Villena A. B polymorphism and its relationship with HLA antigens in a sample of spanish population: high BfFl frequencies. Tissue Antigens 1981; 17: 231-7.

19 Regueiro J R, Arnaiz Villena A. Immunofixation for C2 typing: C2 allotypes in Spaniards in relation to HLA, B and $\mathrm{C} 4$. Hum Genet 1985; 71: 58-61.

20 Fielder A H L, Walport M J, Batchelor J R, et al. Family study of the MHC in patients with systemic lupus erythematosus: importance of null alleles of $\mathrm{CAA}$ and $\mathrm{CAB}$ in determining disease susceptibility. $B M F$ 1983; 286: 425-8.

21 Kemp M E, Atkinson J P, Skanes V M, Levine R P, Chaplin $D$ D. Deletion of C4A genes in patients with systemic lupus erythematosus. Arthritis Rhewm 1987; 30: 1015-22.

22 Sato K, Myasaka N, Yamaoka K, et al. Discordant interleukin 2 production in monozygotic twins concordant for systemic lupus erythematosus. Autoimmunity 1988; 2: 3-10. 